\title{
The Environment, The World System $\&$ The Muslim Scholar
}

The causal link between the environmental crisis and scholarly activities may seem untenable at first glance. After all, what could scholars do, one may ask, to improve the environment? Common sense suggests that this is the domain of environmental science and engineering, not the task of humanities and social sciences; scholars ought not to be occupied with how many species are disappearing, as that seems to be the domain of biologists. If pollution is getting out of control, it must be due to the irresponsibility of policy makers whose inefficiency may seem to be the cause of it.

If the humanities and social science scholars venture out of their specializations, they will find that they have everything to do with the rapidly deteriorating environment. By seeing the world holistically, they can identify the impending environmental crisis and help save the environment by studying the causal factors of its destruction. Conversely, they should bear in mind that their absence from this field will lead directly to its further deterioration. A better future lies in the activities of those scholars whose efforts can help create an environment conducive to sustaining the quality of life, not with the scholars who are preoccupied with choosing routes to economic and political modernity that will yield maximum economic growth and material wealth.

Shifting from economics to political science, one finds that 'security', a notion central to the field, has acquired a different meaning. It is not military security or internal security of one or several states alone that defines the field, but environmental security, which is common to the whole planet. Deforestation exists because there is a market for timber, which is not due to the needy people who want to build a shack to live in, but due to the profit seekers whose activities have become devoid of ethics. Market is supposedly apolitical but it is also unethical. The population explosion, which is a direct result of certain distinct developments in the field of modern medicine, is at the core of environmental destruction. It took 130 years for the world population to grow from one to two billion but it will take just a decade to climb from five billion to six billion! The debate 
between Cornucopians (those who have faith in unlimited resources, futurism, technologism and market-driven human ingenuity) versus the Neo-Malthusians (those who are pessimistic about the world system because it has wrought upon us the degradation of soil, the greenhouse effect, hyper-consumption and toxic waste), has well-nigh become central to most academic disciplines. The population explosion, which leads to hyper-urbanism and a host of other problems, is central to understanding the sociologist's inquiry, who wonders why in the world's most affluent society, the need for both parents to work takes higher priority than the child's well-being, at a time when drug addiction and teen pregnancy is an everyday risk? The social, political and economic trends of the modern world have also brought us to the current impasse and the incipient destruction of the environment that shapes the paranoia within the wealthiest and "most secure" of all the societies.

It is exigent that Muslim scholars not only study the social and scientific effects of environmental depletion, but look into the causes of it and then develop a philosophically and ethically coherent response that informs their inquiry and offers remedies to its pernicious effects.

\section{The Problem}

The idea of economic growth, according to the existing paradigms is often taken as a measure of the wealth and power of societies . Judging a state is judging how developed it is because underdevelopment is considered a curse in the contemporary vocabulary. Economic development and growth are considered to be normatively superior by policy makers, and agrarian economies (which are more sustainable and environment friendly) are looked upon as backward. The political ideology of "economic growth", upon which capitalist production rests, has ironically given birth to very irrational standards: a society that produces more, consumes more and litters more is considered better than a society which produces according to its needs, consumes with thrift, and whose industry produces no toxic waste.

Among the development models, the communist variant of development and growth, which also led to horrendous environmental damage, is not popular anymore for the reasons of being a defeated and defunct ideology. Liberal capitalism of the West has emerged triumphant and presents itself as the universal and normative path of development. Despite the fact that the rich get richer, the poor poorer and moral values 
are rapidly deteriorating, capitalist development and accumulation is gradually becoming purer, the state is becoming more intrusive and the legitimacy of both to a large extent remains unquestioned.

North America and Australia notoriously took the lead in Time magazine's special issue on environment as the "Biggest Offenders" of the world, while Europe, Russia and Japan followed closely. Samuel Huntington's analysis that the "West is Unique" is not convincing any more as one looks at the destruction of the environment in Japan and China. Neither does Francis Fukuyama's "triumph of democratic capitalism" seem plausible, given the pitiable record of waste that these societies produce. If the rest of the world were to become like these militarily powerful but filth polluting nations, then shorelines would recede more rapidly and degradation of life would accelerate at a much faster pace. Ironically, on Time's map of the "world offenders", the least offensive to the environment was the Muslim world. If this is true, shouldn't the so-called "backward" nations of the world tell the World Bank and IMF how to run their economies in a more "environmentally friendly" way?

Despite the fact that the visible rubbish and dust in the poor Muslim nations is high, according to the newest charts and tables on the environment, they are the most environment-friendly people. Most of their visible litter is a consequence of mimicking the industrial world and lack of policies that "hide" or export their toxic garbage overseas. As the poor recipients of international industrial garbage, they cannot afford to ship their own waste elsewhere. For the globe as a whole, this visible litter is less damaging than the invisible toxic waste that is hidden in the hinterland of Industrial nations, or exported to the third world nations for a sum that is literally crumbs of the world economy.

\section{The Predicament}

The Muslim predicament, nonetheless, is difficult: Those Muslims who want to become politically and militarily strong must keep in mind that by trying to race with the industrial West, they will have to become like it, at least in their pattern of industrial production. This is more bad news for the planet. The Muslim quandary, it seems, is either to stay weak in the military-industrial complex and be environment-friendly, or to hasten the death of the environment by joining the growth and development rat-race. Because the route to the Muslims' development and growth is blocked as a result of the unfair and discriminatory practices of industrial nations whose 
product the world system is, the only logical route they can take in order to be out of this morass is to put the paradigms such as growth and development in their proper place by providing a superior normative intellectual challenge to such aberrant concepts. This necessitates a path of knowledge combined with spiritual ethics for the contemporary Muslim scholars. Muslims can only improve their own living if they can demonstrate that the prevalent world system's fetish with economic growth is inferior to an economy of subsistence and balance. In order for Muslims to breathe fresh air and drink clean water, they must first help the polluters understand these principles. For Muslims to accomplish just that, they need to be aware of the historical and intellectual changes in world history that are rapidly leading to the destruction of the environment.

\section{Causes}

Since the Enclosure Movement in England and the gradual development of capitalism as a world system, the serenity and beauty of the environment has gradually been destroyed. The record shows that the capitalist socio-economic formation, as it arose from a secularizing Europe, is based upon the logic of excessive production and proliferation motivated by profit, which is not compatible with environmental sustainability.

Ironically, today's corporations, whose ethical and legal practices (thanks to globalization) are sometimes beyond the manacles of the nation-state, are responsible for the proliferation of toxic waste, yet it is they who are in the forefront posing as the friends of environment. This further exacerbates the damage to the environment because an average person is forced to dwell in a fool's paradise. Those scholars who could care, think of environmentalism as a secondary cause good only for pseudonaturalist/activists who are anarchic degenerates against all development and progress.

Most ironical fact is that the environmentalists (scientists and activists both) are aware of the acute dangers due to the erosion of the environment such as an exponential population explosion, dwindling resources, social conflict \& genocide, yet they are hardly aware of the cause and effect relationship inherent in industrialism and the biophysical limits of the globe. A vast majority of these scientists talk of the environmental catastrophe, yet conclude with the need for more development, a policy prescription which will certainly lead to further destruction of natural surroundings! Paradoxically, the very reason through which the modern 
world system could become the cause of total environmental catastrophe is sometimes looked upon as a solution for fixing the environmental damage. It is like giving the victim of poison some more poison!

The excessive abuse of nature is a direct result of man's rebellion against God. This state of rebellion gave birth to the development of secularism and the securlarization of sciences in the West. Practicing science is one thing, but its modern application by people with a radically secular worldview has had ruinous consequences, whose effects took a few centuries to realize. Most scientists agree that this has been due to and caused by a disequilibrium between man and nature. Contemporary man, in his quest for security, is out to dominate and control all aspects of nature, as opposed to his predecessor, who lived in harmony with nature.

It is our endeavor to offer remedial help to this despicable state through re-infusing the transcendental ideals that were forgotten for being a drag on progress. The vertical axis of Tawheed that runs through the entire worldview, world system and system of knowledge and sciences, needs to become central informant of our research ethics. The inseparable link between human beings and their natural environment is a middle path, which allows for change but not disruption. One may grow but not waste. The modern world system is in dire need of such an intellectual discourse, which can be a great aid in awakening the dormant possibilities within other religious traditions that are at the mercy of modernism.

Environmental degredation is a direct consequence of intellectual insensitivity, material lust and spiritual poverty. It is incumbent upon the morally committed intellectuals to combine knowledge, piety and activism, so that the very natural and blessed act of having children and leaving our posterity behind us is not fraught with the fears of disaster. Parents like to leave their children in a secure and serene garden, not in a tormented house of misery. Unbridled and excessive consumption has led humanity to burdensome and poor life quality; it is now time for all men to reverse that intellectual process so that it helps the earth to recover from illness and return to its balance.

Ejaz Akram 